\title{
ANALISIS PENERAPAN PSAK 109 MENGENAI AKUNTANSI ZAKAT DAN INFAQ/SEDEKAH PADA BAITUL MAL ACEH
}

\author{
Murniati $^{1}$, Adhisyahfitri Evalina Ikhsan ${ }^{* 2}$ \\ 1,2Program Studi Akuntansi Fakultas Ekonomi dan Bisnis Universitas Syiah Kuala \\ e-mail: murniati.au@gmail.com ${ }^{1}$, adhisyahfitri.evalina@unsyiah.ac.id ${ }^{2}$
}

\section{* Corresponding Author}

\begin{abstract}
Abstrak
This research aims to analyze the implementation of PSAK 109 in Baitul Mal Aceh. This research was conducted to look how PSAK 109 was applied in Baitul Mal Aceh. This research uses questionare as the primary data and financial statement as the secondary data. The subject of this research is Baitul Mal Aceh and the object is financial statement of 2016 period. This research is a descriptive research, data analysis in this study uses descriptivecomaparative analysis. The result of this study shows that there are four indicators of PSAK 109. Baitul Mal Aceh has applied 94\% of PSAK 109.
\end{abstract}

\section{Keywords: PSAK 109, Baitul Mal Aceh, Zakat and infaq/sedekah, Financial Statement}

\section{Pendahuluan}

Indonesia merupakan salah satu negara dengan jumlah mayoritas penduduk beragama Islam. Keadaan tersebut menjadikan perkembangan berbagai sektor yang berbasis syariah di Indonesia telah menunjukkan perkembangan menuju arah yang positif. Salah satunya yaitu perkembangan dalam sektor perekonomian. Hal tersebut ditandai dengan munculnya berbagai institusi syariah dalam bidang perekonomian, mulai dari sektor perbankan syariah, pasar modal syariah, hingga asuransi syariah. Berbicara mengenai sektor perbankan syariah, banyak masyarakat yang telah memilih jasa perbankan syariah sebagai alternatif, baik simpanan maupun pinjaman. Selain itu, pesatnya perkembangan ekonomi syariah juga ditandai dengan munculnya Lembaga Amil Zakat, Badan Amil Zakat, dan Baitul Mal sebagai lembaga pengelola zakat. Adanya Lembaga Amil Zakat atau sejenisnya dimaksudkan sebagai institusi pengelola zakat dengan tujuan pemerataan kesejahteraan.

Zakat merupakan salah satu rukun Islam yang diwajibkan untuk setiap muslim yang memiliki harta. Esensi zakat dalam Islam bukan hanya sebagai ibadah semata, namun memiliki tujuan lain yang lebih komprehensif. Adapun tujuan dari zakat adalah sebagai pendistribusian kekayaan dari pihak yang mampu kepada pihak yang kekurangan harta, sehingga terjadi pemerataan
Kekayaan untuk mencegah kesenjangan sosial. Kemunculan suatu badan yang berfungsi sebagai lembaga pengelola zakat sangat diperlukan mengingat zakat harus dikelola dengan baik oleh lembaga yang berwenang guna mencapai kesejahteraan dan pemerataan kekayaan sebagaimana yang diinginkan. Oleh karena itu, kemunculan lembaga pengelola zakat seperti Badan Amil Zakat, Lembaga Amil Zakat dan Baitul Mal mendapat tanggapan yang baik dari masyarakat.

Negara telah menyadari bahwa zakat memiliki peran yang besar bagi ummat. Indonesia telah memberlakukan Undang-Undang No.38 Tahun 1999 tentang Pengelolaan Zakat (Nurhayati \& Wasilah, 2015:282). Pengelolaan zakat di Indonesia telah mengalami banyak perkembangan yang dinamis. Zakat nasional secara resmi bertransformasi dari rezim desentralisasi zakat di bawah UU No. 38/1999 ke rezim sentralisasi zakat di bawah UU No.38/2011 (Wibisono, 2015:113). Pemerintah menyadari bahwa permasalahan ekonomi dan sosial dalam masyarakat dapat ditekan, salah satunya dengan pengelolaan zakat yang baik, transparan serta bertanggungjawab.

Lembaga pengelola zakat merupakan suatu organisasi nirlaba yang tidak berorientasi pada keuntungan. Sebagai sebuah lembaga publik, lembaga pengelola zakat juga memiliki para stakeholder yang memiliki kepentingan terhadap lembaga tersebut. Oleh 
karena itu, kemampuan lembaga pengelola zakat untuk dapat memberikan pertanggungjawaban kepada para pemangku kepentingannya merupakan hal yang sangat penting. Pertanggungjawaban tersebut berupa pelaporan keuangan. Sebagaimana organisasi konvensional, lembaga pengelola zakat sebagai organisasi yang berbasis syari'ah juga mutlak membutuhkan suatu standar baku dalam pelaporan keuangannya.

Hingga saat ini, IAI (Ikatan Akuntan Indonesia) telah mengeluarkan beberapa standar akuntansi yang berbasis syariah. Salah satu dari standar tersebut adalah PSAK 109 mengenai zakat dan infaq/sedekah. PSAK 109 berisi pedoman pengungkapan, pengukuran, serta penyajian laporan keuangan bagi lembaga amil zakat atau lembaga pengelola zakat. Standar yang diatur dalam PSAK 109 tersebut dimaksudkan agar terdapat keseragaman dalam penyusunan laporan keuangan bagi lembaga zakat atau badan amil zakat sehingga memudahkan para pemangku kepentingan atau para pengambil keputusan untuk memahami pelaporan keuangan yang berhubungan dengan zakat dan infaq/sedekah. Penerapan standar akuntansi yang sama bagi setiap lembaga pengelola zakat akan memudahkan para pengguna laporan keuangan untuk membandingkan laporan keuangan suatu lembaga pengelola zakat dengan lembaga pengelola zakat lain sehingga dapat digunakan sebagai acuan pengambilan keputusan bisnis.

PSAK (Pernyataan Standar Akuntansi Keuangan) 109 mengenai zakat dan infaq/sedekah mulai diterbitkan oleh IAI pada tanggal 6 April 2010, kemudian mulai diterapkan dan bisa dirasakan publik pada September 2011 (Listyowati, Murti dan Chomsatu. 2016). Walaupun IAI telah menerbitkan PSAK 109 mengenai pelaporan keuangan khusus untuk lembaga pengelola zakat, infaq/sedekah, namun masih terdapat beberapa lembaga pengelola zakat atau badan amil zakat yang hingga saat ini belum menerapkan PSAK 109. Shahnaz (2015) melakukan penelitian pada Badan Amil Zakat provinsi Sulawesi Utara. Hasil dari penelitian tersebut menunjukkan bahwa Badan Amil Zakat provinsi Sulawesi Utara belum menerapkan penyusunan laporan keuangan sebagaimana yang terdapat dalam format laporan akuntansi keuangan zakat, infaq/sedekah sesuai PSAK 109. Penelitian yang sama juga dilakukan oleh
(Anggreini, Pangemanan dan Rondonuwu. 2016) pada BAZNAS Kota Bitung. Penelitian tersebut menunjukkan bahwa BAZNAS Kota Bitung belum menerapkan PSAK 109 dalam pelaporan keuangannya. Hal itu dapat dikarenaka oleh beberapa hal, yaitu Badan Amil Zakat masih menyajikan laporan keuangan sesuai dengan keperluan amil, belum merujuk pada standar akuntansi sebagaimana yang tedapat dalam PSAK 109.

Lembaga pengelola zakat di Aceh terbentuk sejak tahun 1973 dengan adanya keputusan Gubernur Daerah Istimewa Aceh No. 05/1973 dengan nama Badan Penertiban Harta Agama (BPHA). Pada tahun 1975 BPHA diubah menjadi Badan Harta Agama (BHA). Lembaga ini telah beberapa kali mengalami perubahan nama, sebelum akhirnya ditetapkan dengan nama Baitul Mal Aceh pada Januari 2008 berdasarkan Qanun Aceh Nomor 10 Tahun 2007. Qanun Aceh Nomor 10 Tahun 2007 menyebutkan bahwa Baitul Mal Aceh merupakan lembaga daerah non struktural yang merupakan turunan dari UUPA yang dapat menjalankan tugasnya secara independen dan sesuai dengan ketentuan syari'at serta bertanggungjawab kepada Gubernur. Adapun wewenang Baitul Mal adalah melakukan pengelolaan dan pengembangan terhadap zakat, waqaf dan harta agama lainnya yang bertujuan untuk kesejahteraan masyarakat serta menjadi wali/wali pengawas terhadap anak yatim piatu dan/atau menjadi pengelola terhadap harta warisan bagi yang tidak memiliki wali berdasarkan ketentuan syari'at.

Peran Baitul Mal Aceh sebagai sebuah lembaga yang bersifat resmi dan independen telah diatur dalam Undang-Undang No.11 Tahun 2006 pasal 191, yang disebutkan bahwa zakat, harta waqaf dan harta agama lainnya dikelola oleh Baitul Mal Aceh dan Baitul Mal Kota. Undang-Undang No.11 Tahun 2006 pasal 180 ayat (1) huruf d disebutkan bahwa zakat meupakan bagian dari Pendapatan Asli Daerah (PAD) yang pengelolaannya tunduk pada pedoman perundangundangan. Sebagai sebuah lembaga yang berbasis syariah, Baitul Mal tidak hanya harus tunduk kepada peraturan pemerintahan, namun juga harus tunduk kepada aturan yang berlaku dalam syariat Islam. Hal tersebut juga berkaitan dengan sistem pengelolaan dan penyaluran zakat, dimana zakat harus dikelola dan disalurkan secara benar sesuai dengan ketentuan yang berlaku dalam Islam. 
Jika zakat dijadikan salah satu bentuk PAD (Pendapatan Asli Daerah), maka hal tersebut berati bahwa zakat dapat digunakan sebagai sumber belanja daerah dan dapat dimasukkan dalam RAPBD, sedangkan dalam ketentuan Islam, zakat dikelola oleh amil dan disalurkan sesuai dengan asnaf (golongan) yang telah ditentukan. Zakat juga tidak dapat digunakan untuk membiayai kegiatan pemerintah, dan harus disalurkan sesuai waktunya tanpa harus menunggu pengegesahan APBD. Namun jika zakat dijadikan salah satu sumber PAD, penyaluran zakat harus berdasarkan pengesahan APBD. Hal tersebut jelas berbeda dengan ketentuan zakat yang diatur dalam syariat Islam. Keadaan tersebut telah menjadi masalah tersendiri dalam memahami peran Baitul Mal Aceh. Oleh karena itu, perlu adanya pedoman atau regulasi yang tepat untuk meningkatkan kepercayaan masyarakat terhadap Baitul Mal Aceh.

Hingga saat ini, Baitul Mal Aceh telah merealisasikan banyak program dalam hal penyaluran dana ZIS (Zakat, Infaq, Sedekah) dengan tujuan distribusi kekayaan dan pemerataan kesejahteraan. Penyaluran zakat kepada 8 (delapan) asnaf dilakukan dengan beberapa program oleh Baitul Mal Aceh, yaitu berupa pinjaman modal usaha tanpa bunga kepada ribuan fakir miskin di Aceh guna meningkatkan taraf hidup masyarakat. Program lain yang juga dilaksanakan oleh Baitul Mal Aceh adalah pemberian bantuan berupa alat kerja dalam bidang pertanian, perdagangan dan industri rumah tangga. Selain itu, Baitul Mal Aceh juga menyalurkan bantuan pendidikan kepada mahasiswa yang berasal dari keluarga kurang berada, guna meningkatkan taraf pendidikan para generasi muda Aceh.

Penerimaan dana zakat, infaq dan sedekah Baitul Mal Aceh dan Baitul Mal Kabupaten/Kota seAceh mengalami peningkatan pada tahun 2016 sebesar Rp 237 Milyar dibandingkan periode sebelumnya sebesar Rp 220 Milyar. Hal tersebut menunjukkan bahwa Baitul Mal sebagai lembaga pengelola zakat memiliki peran penting dalam meningkatkan taraf hidup masyarakat, oleh karena itu peran Baitul Mal mendapatkan tanggapan positif dari masyarakat. Meningkatkan kepercayaan masyarakat merupakan suatu hal yang harus terus dilakukan oleh Baitul Mal dengan berbagai program inovatif. Oleh karena kepercayaan merupakan sesuatu yang penting, maka peningkatan transparansi merupakan suatu keharusan.
Sebagai lembaga pengelola zakat resmi, Baitul Mal memiliki peran dan fungsi yang penting dalam membangun perekonomian, oleh karena itu pelaporan keuangan dengan suatu standar baku yang telah ditentukan merupakan suatu hal yang sangat penting pula. Oleh karena tujuan dari penerapan PSAK 109 adalah untuk keseragaman pelaporan keuangan lembaga pengelola zakat, maka sudah seharusnya lembaga pengelola zakat menerapkan standar tersebut.

\section{Kerangka Teoritis \\ Zakat}

Secara bahasa zakat berarti mensucikan, tumbuh atau berkembang. Menurut syara', zakat berarti menyisihkan sebagian harta tertentu untuk disalurkan kepada pihak yang berhak menerima sesuai dengan syarat dan ketentuan dalam islam (Wibisono, 2015 : 1). Zakat merupakan salah satu rukun islam yang menjadi unsur utama instrumen kebijakan fiskal dalam perekonomian islam. zakat terbagi dua, yaitu zakat fitrah dan zakat mal.

Menurut Ayyub (2011 : 553) zakat fitrah adalah harta yang dierikan kepada orang yang berhak menerima secara khusus, dikatakan fitrah karena dikeluarkan setelah melaksanakan puasa ramadhan. Zakat mal merupakan bagian harta yang disisihkan oleh individu muslim atau badan usaha yang dimiliki dengan ketetapan agama untuk diberikan kepada yang berhak menerimanya. Pihak yang mengeluarkan zakat dizebut muzakki dan pihak yang berhak menerima zakat disebut mustahiq. Mustahiq terdiri dari delapan golongan, yaitu: fakir, miskin, amil, muallaf, hamba sahaya, orang yang berhutang dan ibnu sabil. Adapun zakat yang dkeluarkan memiliki syarat dan rukun tertentu dalam islam.

\section{Infaq/sedekah}

Infaq berarti mendermakan, memberikan atau menafkahkan sebagian rezeki pemberian Allah kepada orang lain berdasarkan pada keikhlasan karena Allah SWT. Sedekah berasal dari kata shadaqa yang berarti benar. Sedekah merupakan suatu akad pemberian suatu benda kepada orang lain karena mengharapkan pahala dan keridhaan dari Allah. Perbedaan infaq dan sedekah terletak pada benda atau objek pemberian. Infaq berkaitan dengan pemberian berupa barang sedangkan sedekah dapat berupa barang maupun non barang, tenaga atau jasa. 


\section{Jenis-Jenis Harta Wajib Zakat}

Zakat memiliki syarat-syarat dan rukun tertentu yang telah diatur dalam ketentuan agama. Ketentuan tersebut meliputi jenis-jenis harta yang wjaib dizakati, yaitu:

a. Zakat hewan ternak

b. Zakat emas dan perak

c. Zakat perdagangan

d. Zakat pertanian

\section{Dasar Hukum dan Manfaat Zakat}

Hukum zakat adalah wajib sebagaimana terdapatdalam Al-Quran surah Al-Muzammil ayat 20 yang artinya " dirikanlah shalat dan tunaikanlah zakat". adapun manfaat zakat adalah untuk mengangkat derajat fakir miskin dan membantunya keluar dari kesulitan dan penderitaan serta sebagai sarana pemerataan pendapatan untuk mencapai keadilan sosial (Mardani, 2015 : 374).

\section{Kerangka Pemikiran}

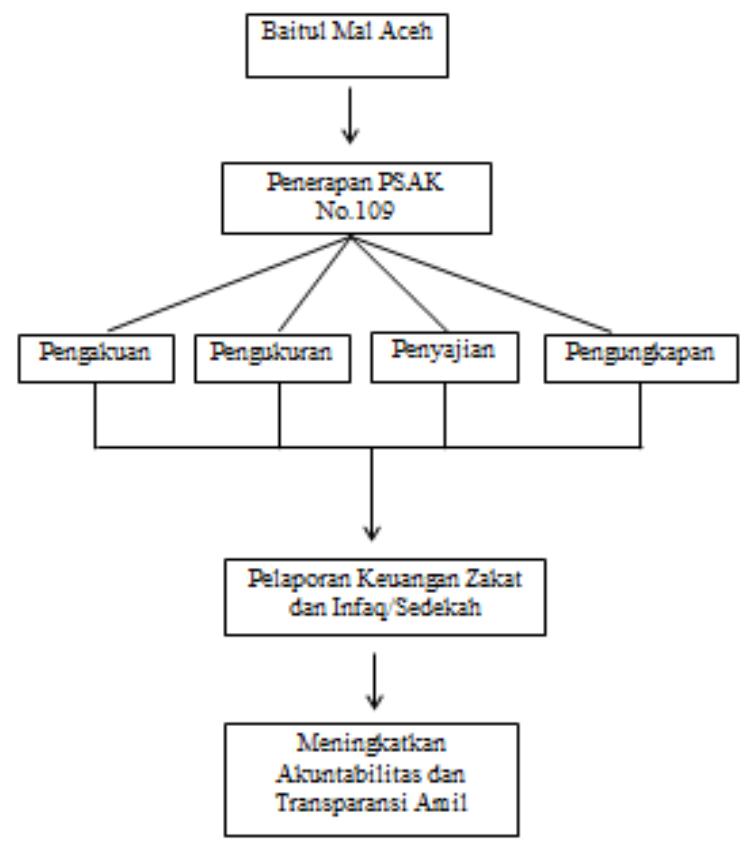

\section{Metode Penelitian}

Penelitian berpedoman pada kerangka penelitian yang dikemukakan oleh Sekaran yang memuat aspek sebagai berikut:

1. Tujuan Penelitian

Penelitian ini bertujuan untuk menganalisis penerapan PSAK 109 pada Baitul Mal Aceh.

2. Jenis Penelitian
Penelitian ni merupakan penelitian deskriptif yang menjelaskan analisis penerapan PSAK 109 pada Baitul Mal Aceh.

3. Tingkat Intervensi Peneliti

Tingkat intervensi peneliti adalah intervensi minimal.

4. Situasi Penelitian

Situasi yang digunakan dalam penelitian ini adalah situasi tidak diatur.

5. Unit Analisis

Dalam penelitian ini unit analisis yang digunakan adalah tingkat organisasional.

6. Horizon Waktu

Penelitian ini menggunakan horizon waktu crosssectional studies, data dikumpul pada satu periode.

Subjek dalam penelitian ini adalah Baitul Mal Aceh. Objek dalam penelitian ini adalah laporan keuangan Baitul Mal aceh tahun 2016. Data tang digunakan adalah data primer dan data sekunder. Penelitian ini merupakan penelitian deskriptif, metode analisis data adalah analisis deskriptif-komparatif.

\section{Hasil Dan Pembahasan}

Analsis penerapan PSAK 109 pada Baitul Mal Aceh dilakukan dengan menganalisis laporan keuangan dan melakukan pengukuran yang mengacu pada PSAK 109.

\section{Analisis Laporan Keuangan Baitul Mal Aceh}

Baitul Mal Aceh menyajikan 4 (empat) jenis laporan keuangan yaitu laporan posisi keuangan, laporan perubahan dana, laporan arus kas dan catatan atas laporan keuangan. Pada laporan posisi keuangan, Baitul Mal Aceh telah menyajikan akun-akun yang sesuai dengan format laporan keuangan sebagaimana yang terdapat dalam PSAK 101. Adapun akun-akun yang disajikan dalam laporan posisi keuangan berupa akun aset lancar, aset tidak lancar, liabilitas dan saldo dana. Pada bagian saldo dana, Baitul Mal Aceh tidak memasukkan dana amil pada bagian saldo dana, sedangkan menurut format laporan keuangan berdasarkan PSAK 101, dana amil dimasukkan pada bagian saldo dana. Hal ini disebabkan karena pada Baitul Mal Aceh, dana amil tidak diambil dari dana zakat.

Laporan perubahan dana berisi akun-akun berupa dana zakat, dana infaq/sedekah dan dana amil. 
Laporan perubahan dana yang disajikan Baitul Mal Aceh berisi akun-akun dana zakat, dana infaq/sedekah dan dana lainnya. Baitul Mal Aceh tidak menyajikan dana amil dalam laporan perubahan dana, hal tersebut dikarenakan dana amil tidak diambil dari dana zakat. Baitul Mal Aceh tidak menyajikan laporan perubahan aset kelolaan, hal ini dikarenakan sampai saat ini Baitul Mal Aceh belum memiliki aset kelolaan.

Laporan arus kas Baitul Mal Aceh berisi akunakun kas masuk dan kas keluar serta kenaikan/penurunan kas bersih. Format laporan arus kas amil tidak diatur secara khusus dalam PSAK 101, hal tersebut karena tidak adanya perbedaan antara laporan arus kas amil dan laporan arus kas yang disajikan untuk entitas lainnya.

\section{Pengukuran yang Mengacu pada PSAK 109 Pengakuan dan Pengukuran}

Indikator pengakuan dan pengukuran terdiri dari 30 (tiga puluh) poin, dimana setiap poin mengatur bagaimana pengakuan dan pengukuran dana zakat dan infaq/sedekah berdasarkan PSAK 109. Berdasarkan hasil yang didapat, Baitul Mal Aceh telah melakukan pengakuan yang telah sesuai dengan ketentuan PSAK 109, seperti halnya pengakuan zakat pada saat kas atau aset nonkas diterima. Aset nonkas yang diterima ditentukan berdasarkan nilai pasar, jika tidak tersedia maka menggunakan nilai wajar. Pengakuan yang tidak sesuai dengan poin pada PSAK 109 terdapat pada poin delapan dan sebelas. Poin delapan menjelaskan bahwa efektivitas dan efisisensi pengelolaan dana zakat disebabkan oleh profesionalisme amil. Amil berhak mengambil bagian dari dana zakat untuk menutup biaya operasional dalam rangka melaksanakan fungsinya sesuai kaidah yang berlaku. Baitul Mal Aceh belum menerapkan poin tersebut dikarenakan Baitul Mal aceh tidak mengambil bagian dana amil dari dana zakat.

Poin sebelas menyatakan bahwa bagian dana zakat yang disalurkan untuk amil diakui sebagai penambah dana amil. Baitul Mal Aceh belum menerapkan poin tersebut, hal tersebut dikarenakan dana amil tidak diambil dari dana zakat. Selanjutnya mengenai pengakuan dan pengukuran, Baitul Mal Aceh mengakui zakat telah disalurkan jika dana zakat tersebut sudah diterima oleh mustahik. Baitul Mal Aceh tidak mengakui sebagai penyaluran zakat jika dana zakat yang telah diserahkan kepada mustahik nonamil dan harus dikembalikan kepada amil.

\section{Penyajian}

Indkator penyajian berisi pernyataan mengenai penyajian dana zakat, dana infaq/sedekah dan dana amil secara terpisah dalam laporan posisi keuangan. Baitul Mal telah menyajikan dana zakat dan dana infaq/sedekah pada laporan posisi keuangannya. Hal tersebut menunjukkan bahwa Baitul Mal Aceh telah melakukan penyajian dana zakat dan dana infaq/sedekah sesuai dengan PSAK 109.

\section{Pengungkapan}

Baitul Mal Aceh telah melakukan pengungkapan berdasarkan PSAK 109 mengenai transaksi zakat dan infaq/sedekah. Hal-hal yang diungkapkan berdasarkan PSAK 109 berupa kebijakan penyaluran zakat yang berupa penentuan skala prioritas penyaluran zakat kepada mustahik nonamil. Baitul Mal Aceh juga telah melakukan kebijakan penyaluran zakat untuk amil dan mustahik nonamil seperti persentase pembagian, alasan pembagian dan konsistensi kebijakan. Pengungkapan juga dilakukan untuk menentukan metode nilai wajar yang digunakan untuk penerimaan berupa aset nonkas. Baitul Mal Aceh juga telah melakukan pengungkapan yang sama untuk pengungkapan dana infaq/sedekah. Selain melakukan pengungkapan mengenai dana zakat dan infaq/sedekah. Baitul Mal Aceh juga melakukan pengungkapan mengenai keberadaan dana nonhalal serta kebijakan atas penerimaan dana, alasan serta jumlah dari dana nonhalal tersebut. Baitul Mal Aceh juga mengungkapkan kinerja amil atas penerimaan dan penyaluran danazakat serta dana infaq/sedekah.

Persentase Penerapan PSAK 109

\begin{tabular}{|l|l|l|l|l|}
\hline No & \multicolumn{1}{|c|}{ Indikator } & \multicolumn{1}{|c|}{$\begin{array}{c}\text { Jumlah } \\
\text { Pernyataan }\end{array}$} & $\begin{array}{c}\text { Jumlah yang } \\
\text { telah Diterapkan }\end{array}$ & $\begin{array}{c}\text { Persentase } \\
\text { Penerapan }\end{array}$ \\
\hline 1. & Pengakuan dan & 30 pernyataan & 27 pernyataan & $90 \%$ \\
\hline pengukuran & Penyajian & 1 pernyataan & 1 pernyataan & $100 \%$ \\
\hline 3. & Pengungkapan & 16 pernyataan & 15 pernyataan & $93,25 \%$ \\
\hline
\end{tabular}




\section{Kesimpulan, Keterbatasan Dan Saran}

\section{Kesimpulan}

1. Baitul Mal Aceh dapat dikatakan telah menyajikan laporan keuangan sebagaimana yang terdapat dalam PSAK 109.

2. Baitul Mal Aceh belum menyajikan laporan perubahan aset kelolaan dikarenakan sampai saat ini Baitul Mal Aceh belum memiliki aset kelolaan. Walau demikian, dapat dikatakan bahwa Baitul Mal Aceh telah menyajikan laporan keuangan berdasarkan PSAK 109 walaupun belum diterapkan secara sepenuhnya.

3. Indikator berupa pengakuan dan pengukuran, penyajian serta pengungkapan berdasarkan pernyataan dalam PSAK 109 juga telah diterapkan oleh Baitul Mal Aceh walaupun penerapan belum dilakukan sepenuhnya.

4. Berdasarkan hasil analisis data, didapatkan persentase penerapan PSAK 109 pada Baitul Mal Aceh sebanyak $94 \%$. Hal tersebut menunjukkan bahwa Baitul Mal Aceh telah melakukan pengelolaan zakat dan infaq/sedekah dengan baik sesuai dengan PSAK yang berlaku.

\section{Keterbatasan}

Adapun keterbatasan dalam penelitian ini adalah peneliti tidak melakukan wawancara secara lebih rinci untuk mendapatkan informasi yang menyeluruh mengenai penerapan PSAK 109 pada Baitul Mal Aceh. Peneliti juga tidak melakukan studi lebih lanjut mengenai alasan yang lebih rinci Baitul Mal Aceh terkait beberapa poin dari pernyataan yang terdapat dalam PSAK 109 yang sampai saat ini belum diterapkan oleh Baitul Mal Aceh.

\section{Saran}

1. Sampai saat ini Baitul Mal Aceh telah menyajikan laporan keuangannya yang berlandaskan pada PSAK 109, walaupun penerapan PSAK 109 belum sepenuhnya dilakukan. Penerapan PSAK 109 sepenuhnya perlu dilakukan oleh Baitul Mal Aceh untuk lebih meningkatkan transaparansi dan akuntabilitasnya terhadap pengelolaan zakat dan infaq/sedekah, serta meningkatkan kepercayaan masyarakat.

2. Bagi peneliti selanjutnya, teknik wawancara dapat dilakukan secara lebih rinci agar informasi yang didapat mengenai penerapan PSAK 109 pada Baitul Mal Aceh lebih menyeluruh

\section{Daftar Pustaka}

Al-Qur'an dan Terjemah, Departemen Agama RI, Surabaya: Sukses Publishing, 2012.

Angraeni, Febry Elvinda, Sifrid S Pangemanan, Siatje S Rondonuwu. 2016. Penerapan Akuntansi Zakat dan Infaq/Sedekah Berdasarkan PSAK 109 pada Badan Amil Zakat Kota Bitung. Jurnal EMBA.

Ascarya. 2015. Akad dan Produk Bank Syariah. Jakarta: PT Raja Grafindo Persada.

Ayyub, Syaikh Hasan. 2011. Fikih Ibadah. Jakarta: Pustaka Al-Kautsar.

Hasan, M Ali. 2008. Zakat dan Infak : Salah Satu Solusi Mengatasi Problematika Sosial di Indonesia. Jakarta : Prenamedia Group.

Ikatan Akuntan Indonesia, 2017, Standar Akuntansi Keuangan Syariah, PSAK 101 : Penyajian Laporan Keungan Syariah. Jakarta : Salemba Empat.

Ikatan Akuntan Indonesia, 2017, Standar Akuntansi Keuangan Syariah, PSAK 109 : Zakat dan Infaq/Sedekah. Jakarta : Salemba Empat.

Kristin, Ari \& Umi Khoirul Umah. 2011. Penerapan Akuntansi Zakat pada lembaga Amil Zakat (Studi pada LAZ DPU Cabang Semarang). Value Added Vol.7, No.2

Listyowati, Ika., Tri Murti \& Yuli Chomsatu. 2016. Analisis Penerapan PSAK 109 Tentang Akuntansi Zakat dan Infak/Sedekah pada Lembaga Amil Zakat (LAZ) Yayasan Solo Peduli Ummat. Surakarta: Seminar Nasional dan Call Paper Fakultas Ekonomi UNIBA.

Mardani. 2015. Figh Ekonomi Syariah. Jakarta : Prenadamedia Group.

Megawati, Devi \& Fenny Trisnawati. 2014. Penerapan PSAK 109 Tentang Akuntansi Zakat dan Infak/Sedekah pada BAZ Kota Pekanbaru. Jurnal Penelitian Sosial keagamaan.

Musa, Armiadi. 2016. Zakat Sebagai pendapatan Asli Daerah dalam Undang-Undang Pemerintah Aceh. Kanun Jurnal Ilmu Hukum.

Nurhayati, Sri \& Wasilah. 2014. Akuntansi Syariah di Indonesia. Jakarta. Salemba Empat. 
Puspita, Yulifa \& Habiburrochman. 2013. Penerapan PSAK No.109 Atas Pengungkapan Wajib dan Sukarela. Jurnal Akuntansi Multiparadigma.

Sekaran, Uma \& Roger Bougie. 2017. Research Methods for Business: penelitian Untuk Bisnis. Edisi 7. Jakarta: Salemba Empat.

Shahnaz, Sabrina. 2015. Penerapan PSAK No.109 Tentang Pelaporan Keuangan Akuntansi Zakat, Infaq/Sedekah pada BAZNAS Provinsi Sulawesi Utara. Jurnal Berkala Ilmiah Efisiensi.

Triyuwono, Iwan. 2015. Akuntansi Syariah: Perspektif, Metodologi, dan Teori. Jakarta: PT. Raja Grafindo Persada.

Wibisono, Yusuf. 2015. Mengelola Zakat Indonesia. Jakarta: Prenadamedia Group.

Yasin, Ahmad Hadi. 2012. Buku Panduan Zakat.

Dompet Dhuafa 